\title{
Theoretical Foundations of Psychological and Physical Rehabilitation of Patients with Ischemic Stroke
}

\section{Теоретичні основи психологічної та фізичної реабілітації хворих ішемічним інсультом}

\section{Yevhen Kharchenko}

Doctor in Medicine, Professor, Rivne Medical Academy, Rivne (Ukraine)

ORCID ID: https://orcid.org/0000-0002-4340-8503

Researcher ID: http://www.researcherid.com/rid/AAU-7523-2020

E-mail: kharchenko.yevh@gmail.com

\section{Свген Харченко}

Доктор медичних наук, професор, Рівненська медична академія, м. Рівне (Україна)

\section{Liudmyla Komarnitska}

Ph.D. in Philology, Lecturer of the Department of Social Work and Psychology, Podilskyi Special Educational and Rehabilitation Social-Economical College, Kamianets-Podilskyi (Ukraine)

ORCID ID: https://orcid.org/0000-0002-6742-8314

E-mail: kob-1974@ukr.net

\section{Людмила Комарніцька}

Кандидат філологічних наук, викладач кафедри соціальної роботи та психології, Подільський спеціальний навчально-реабілітаційний соціально-економічний коледж, м. Кам'янець-Подільський (Україна)

Address for correspondence, e-mail: kpnu_lab_ps@ukr.net Copyright: (C) Kharchenko Yevhen, Komarnitska Liudmyla

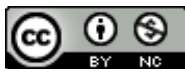

The article is licensed under CC BY-NC 4.0 International

(https://creativecommons.org/licenses/by-nc/4.0/)

(C) Kharchenko Yevhen, Komarnitska Liudmyla DOI (article): https://doi.org/10.32626/2227-6246.2021-52.275-298 
DOI: https://doi.org/10.32626/2227-6246.2021-52

2021. випуск 52

The author's contribution: Kharchenko Ye. $-50 \%$, Komarnitska L. $-50 \%$.

Авторський внесок: Харченко Є. -50\%, Комарніцька Л. - 50\%.

\section{ABSTRACT}

The objectives of our article are: to study the characteristics of disorders of psychomotor function and psycho-emotional state of patients with ischemic stroke according to the initial examination; to develop a method of physical rehabilitation of patients with ischemic stroke at the inpatient stage of rehabilitation, depending on the severity of psychomotor functions and features of the psycho-emotional state; in a psychological and pedagogical experiment to evaluate the effectiveness of the proposed method of physical rehabilitation of patients with ischemic stroke at the inpatient stage of rehabilitation.

The following theoretical methods of the research were used to solve the tasks formulated in the article: a categorical method, structural and functional methods, the methods of the analysis, systematization, modeling, generalization. Also in our research we used empirical methods, such as the observation, the interview, the questionnaire, the method of psychological observation, psychological and medical experiment, testing ( $M$. Lucher's test is used).

The results of the research. It was developed a "Functional methodology for the restoration of motor function of patients with ischemic stroke, taking into account their psycho-physiological features», based on the psychological principles of stepwise, sequencing and complexity, as well as on the maximum and adequate psychological impact of the rehabilitation therapist on the patient.

Also we proposed the "Functional methodology of physical rehabilitation in the early period of ischemic stroke». The main provisions of this methodology are: 1. The stabilization of the psycho-emotional state of the patient: reducing the level of anxiety, increasing motivation to exercise in the course of physical rehabilitation.

2. The actualization of stable static and dynamic stereotypes of the patient in all initial positions - from horizontal to vertical ones, using the influence of simple, eye-motor, tonic (labyrinthine tonic reflexes, symmetrical cervical tonic reflex, cervical asymmetric tonic reflex, etc.). Restoration and maintenance of stress resistance of patients is provided by symmetrical maintenance of a projection of the general center of gravity on a basic surface in such initial positions in which normal proper afferentation of joints and muscles will be stimulated. These are the positions that the human body consistently takes in the process of (C) Kharchenko Yevhen, Komarnitska Liudmyla

DOI (article): https://doi.org/10.32626/2227-6246.2021-52.275-298 
verticalization: a supine position on the back; a lying position on the side (right and left); a supine position; a standing position on the knees; a standing position on the knees (with additional vertical support and without such a support); a standing position (with additional vertical support and without such a support).

It was proved that the starting position became a directly activated position with a torso extension, which had the aim to support all muscle groups of the patient, provided by the stimulation of a successive chain of muscle contractions directed from the center to the periphery of the body. The symmetry of maintaining the initial position of the patient during the lesson is constantly adjusted (passively or actively) in order to stimulate proper afferentation.

Conclusions. The main directions of psychotherapy and psycho-correction of patients who suffered from ischemic stroke are: the assistance in the process of understanding the patients, his / her basic needs, motives, instructions, relationships; his / her internal conflicts and mechanisms of psychological protection; features of his / her behavior and emotional response, their adequacy and realism; the correction of patients' instructions; the assistance in formulating and securing adequate forms of patients' behavior based on personal achievements in the cognitive, motivational, and emotional spheres; the promotion of positive motivation for recovery and increased activity in treatment at the behavioral level.

During the classes according to the proposed methodology, we have the aim to achieve the stabilization of a psycho-emotional state of the patient through the correction of his / her cognitive processes that motivate the patient to actions which generally affect the effectiveness of all rehabilitation measures.

Key words: ischemic stroke, psycho-emotional state of patients, physical rehabilitation, psychological rehabilitation, personal achievements, a cognitive sphere, a motivational sphere, the emotional sphere.

\section{Introduction}

A significant spread of vascular diseases of the brain, which is one of the main causes of disability and mortality, makes them one of the most pressing problems of modern neurology in Ukraine. The incidence of ischemic stroke in Ukraine is 390 per 100000 of population. In Kyiv, according to the Ambulance Service, 50-60 strokes have been registered daily in recent years. At the same time, disability after a stroke is

(c) Kharchenko Yevhen, Komarnitska Liudmyla DOI (article): https://doi.org/10.32626/2227-6246.2021-52.275-298 
DOI: https://doi.org/10.32626/2227-6246.2021-52

2021. випуск 52

$3.2 \%$ of cases per 10000 of population, no more than $17.2 \%$ of people return to their main place of work, and full physical rehabilitation, according to sociological data, is achieved in only $12 \%$ of cases (Mykhalchuk, Pelekh, Kharchenko, Ivashkevych, Ivashkevych, Prymachok, Khupavtseva \& Zukow, 2020).

Motor disorders in the acute period of ischemic stroke are developed in $3 / 4$ of patients, and after six months a persistent motor defect persists in $58 \%$ of patients who have suffered with a stroke. Six months after the stroke, a significant number of patients retain disorders that characterize the main indicators of the activity in everyday life.

The severity of motor disorders, aggravating for this patient and others, explains the desire of the most researchers, primarily to find ways to correct this defect. Physical rehabilitation, in a modern sense, should have the aim at maximizing the use of adaptive and compensatory functions of a sick person in the fight against the disease. One of the main principles of physical rehabilitation is also taking into account the patient's personality, and this determines the close relationships in the rehabilitation program of biological, psychosocial and psychological-pedagogical methods.

The methodological side of the process of psychomotor retraining is also of great importance. The existing classifications of motor disorders do not reflect the complex pathogenetic mechanisms of the formation of post-stroke motor deficit adequately; the clinical structure of motor deficit is insufficiently studied, the peculiarities of the psychological state of the patient, which arose as a result of the disease, are not taken into account. Nowadays, with all the variety of techniques doctors use to restore lost motor function of patients with ischemic stroke, there is no a single system of differentiated use of means and methods of physical rehabilitation, which take into account not only the development of stroke, but also the development of normal motor function in the process of ontogenesis, the possibility of a rational combination of the (c) Kharchenko Yevhen, Komarnitska Liudmyla

DOI (article): https://doi.org/10.32626/2227-6246.2021-52.275-298 
advantages of different schools of movement recovery (kinesitherapy) (Epstein, Blake \& González, 2017).

In this case, the results of psychological research can be used to determine the specifics of the use of motor retraining techniques and assess the effectiveness of rehabilitation measures, as one of the criteria for effective rehabilitation measures and changes of the quality of life to improve psychosocial adaptability of the person.

Thus, it will be very important to create new approaches (methods of physical rehabilitation) to restore motor function of patients with ischemic stroke based on current knowledge about the clinical structure of the disease, the peculiarities of motor skills, as well as knowledge of mental health, which can contribute to more effective recovery that have been damaged.

Cerebral stroke, or cerebrovascular accident, is one of the most common diseases today, and, unfortunately, this disease leads to significant qualitative changes in the lives of a large number of patients each year (Hayden, Farrar \& Peiris, 2014).

According to the WHO, the incidence of stroke varies from 1.5 to 7.4 per 1000 population each year, and in Europe stroke affects more than 1 million people each year (these data were obtained through clinical trials during 2007-2018). It has been established that $1 / 3$ of patients who have suffered because of a stroke are of working age, but only $20 \%$ of them return to work. Mortality due to this disease, according to various authors, is from 17 to $34 \%$ in the first 30 days and $25-40 \%$ during the first year of the disease. Currently, there is a remarkable trend towards some reduction in mortality from ischemic stroke due to early and accurate diagnosis, due to the development of a system of intensive care for stroke (Villar, Blanco \& del Campo, 2015).

The most frequent and severe consequence of cerebral ischemic stroke is the disorder of the motor functions of a person. Characteristic feature is the polymorphism of motor disorders of patients with cerebral ischemic stroke. In this case, general

(C) Kharchenko Yevhen, Komarnitska Liudmyla DOI (article): https://doi.org/10.32626/2227-6246.2021-52.275-298 
for patients is only the loss or violation of arbitrary actions (in the cases of hemiparesis or hemiplezia). Other clinical symptoms are largely variable and depend on a certain extent of the size of affected area, also its localization. According to various authors, persistent disturbances of motor function are also observed in the first days after the disease (in $70-80 \%$ of cases of patients who had the ischemic stroke).

Disorders of voluntary movements in ischemic stroke can be considered as a result of inconsistency of complex motor programs which provide arbitrary motility of the individual. The implementation of such programs is associated primarily with the functioning of complex multifunctional systems, in which the leading role belongs to the central motor neuron, which has numerous connections in subcortical formations, for example - with the reticular formation of the brain stem (Onufriieva, Chaikovska, Kobets, Pavelkiv \& Melnychuk, 2020).

By the attempt to classify motor disorders which take a place when patients have cerebral circulatory disorders, it becomes clear that any disorder can be characterized only by describing it in several paradigms. According to the WHO, pathophysiological signs (from English - impairments) are suitable for the description of any other disorder. Motor disorders can be caused by pathological changes in the muscular, skeletal or nervous systems.

Data on pathophysiological signs in many cases allow only a rough idea of what motor functions can actually be performed. Loss or limitation of functionality is called disabilities, according to the WHO. The difficulty of describing motor disorders, in terms of functional limitations, lies in a large number of opportunities to test these functions. Under conditions of cerebral disorders, the attempts have often been made to make a definite, fairly clear order of motor functions, taking into account models of cerebral control over human movements.

Motor disorders can be distinguished (by the type of their genesis) on primary-organic and psychogenic motor disorders. (C) Kharchenko Yevhen, Komarnitska Liudmyla

DOI (article): https://doi.org/10.32626/2227-6246.2021-52.275-298 
In the case of primary-organic motor disorders pathological changes are observed in the muscular, skeletal or nervous systems, however, in the conditions of psychogenic motor disorders the presence of such changes proved to be objectively impossible. To describe motor disorders of a patient, first of all, it is necessary to know: a) what functions must be distinguished in the cases of the process of motor regulation of a person; b) in what forms the disorders of these functions are revealed. The main differences observed between disorders are: a) initiation of actions; b) frustration in their presentation. In the cases of doing the actions there are disorders of the programmed control, regulation and coordination.

The main characteristic of the regulation of movements is the integration of regulation of motor processes, through which movements are more or less continuously adapted to the world and other autonomous processes, which are often referred to as regulation by a human psychomotor program. The essence of disorders of regulatory processes is manifested primarily in motor disorders that occur when the distortion of feedback takes a place. The essence of autonomous processes that are independent of sensory feedback coming from the periphery of the body, is manifested in the fact that because of the absence of feedback (including feedback from the senses, feedback in the muscles and joints) the ability to move is still preserved (Hardeman, Medina \& Kozhimannil, 2016).

The regulation of movements is also when the movement is initially as if it is listed in the distal relation. Performing a certain action, the muscles should be involved in such a way that the desired result is achieved, in this case we mean the desired psychomotor skills. The relationships between the motor command given to an individual by muscles and the actions we call «movement» as a result of so-called «transformation of the body»; for successful traffic control this transformation must be inverted. Disorders in the case of human mastery of the body transformation are usually processes of disorders'

(c) Kharchenko Yevhen, Komarnitska Liudmyla DOI (article): https://doi.org/10.32626/2227-6246.2021-52.275-298 
DOI: https://doi.org/10.32626/2227-6246.2021-52

2021. випуск 52

coordination: different muscles do not «agree» with each other in the appropriate temporal and / or forceful relationships (Khwaja, 2012).

Disorders that occur in the case of actions of ischemic stroke can be compared with so called «initiated actions». From the functional point of view any action does not start at the moment when any muscles are reduced or relaxed. With the help of physiological and psychological methods it can be proved first of all, that there are processes of preparation for actions, which are often called «programming ones»: the previously formed motion program must be ready and its parameters should be adapted to required action. Such kind of disorder appears sometimes only in a case of performance of certain action and then they can be described as disturbances of purposeful management of the program of a patient. But, according to this, there are disorders that relate to fundamentally different motor programs which have not been programmed by the person.

Thus, taking into account the theoretical and methodological analysis of the scientific literature in our research, the objectives of our article are:

1. To study the characteristics of disorders of psychomotor function and psycho-emotional state of patients with ischemic stroke according to the initial examination.

2. To develop the method of physical rehabilitation of patients with ischemic stroke at the inpatient stage of rehabilitation, depending on the severity of psychomotor functions and features of the psycho-emotional state.

3. In a pedagogical experiment to evaluate the effectiveness of the proposed method of physical rehabilitation of patients with ischemic stroke at the inpatient stage of rehabilitation.

\section{Methods of the research}

The following theoretical methods of the research were used to solve the tasks formulated in the article: a categorical (C) Kharchenko Yevhen, Komarnitska Liudmyla

DOI (article): https://doi.org/10.32626/2227-6246.2021-52.275-298 
DOI: https://doi.org/10.32626/2227-6246.2021-52

2021. ВИПУСК 52

method, structural and functional methods, the methods of the analysis, systematization, modeling, generalization. Also in our research we used empirical methods, such as the observation, the interview, the questionnaire, the method of psychological observation, Psychological and medical experiment, testing (M. Lucher's test is used).

\section{Results and their discussion}

Research methods. The following research methods were used to solve the tasks having been set in our research:

Psychological and pedagogical research methods:

1. The analysis of literature sources.

2. The method of psychological observation.

3. Psychological and medical experiment.

4. Providing the research of psycho-emotional state (M. Lucher's test is used).

For our research we proposed «The author's methodology of measuring the amount of active movements in the joints of the patient's limbs» (Table 1 ).

Table 1

The methodology of measuring the amount of active movements in the joints of the patient's limbs

\begin{tabular}{|l|l|l|}
\hline $\begin{array}{c}\text { Movement which has } \\
\text { measured and the } \\
\text { plane of motor activity }\end{array}$ & \multicolumn{1}{|c|}{$\begin{array}{c}\text { Starting position } \\
\text { of the patient }\end{array}$} & $\begin{array}{c}\text { Indexes of } \\
\text { the volume } \\
\text { of normal } \\
\text { movements }\end{array}$ \\
\hline $\begin{array}{l}\text { Flexion and extension } \\
\text { in shoulder joint; sagit- } \\
\text { tal plane }\end{array}$ & $\begin{array}{l}\text { Sitting or lying on your } \\
\text { back, a hand is along the } \\
\text { torso, unbent in the elbow } \\
\text { joint }\end{array}$ & $\begin{array}{l}\text { Bending - } \\
180 \text { times } \\
\text { Extension - } \\
60 \text { times }\end{array}$ \\
\hline $\begin{array}{l}\text { Withdrawal of the arm } \\
\text { in the shoulder joints; a } \\
\text { frontal plane }\end{array}$ & $\begin{array}{l}\text { Sitting or lying on your } \\
\text { back, hand along the tor- } \\
\text { so, unbent in the elbow } \\
\text { joint }\end{array}$ & $\begin{array}{l}\text { Bending - } \\
180 \text { times } \\
\text { Extension - } \\
180 \text { times }\end{array}$ \\
\hline
\end{tabular}

(C) Kharchenko Yevhen, Komarnitska Liudmyla DOI (article): https://doi.org/10.32626/2227-6246.2021-52.275-298 


\begin{tabular}{|c|c|c|}
\hline $\begin{array}{l}\text { Movement which has } \\
\text { measured and the } \\
\text { plane of motor activity }\end{array}$ & $\begin{array}{l}\text { Starting position } \\
\text { of the patient }\end{array}$ & $\begin{array}{l}\text { Indexes of } \\
\text { the volume } \\
\text { of normal } \\
\text { movements }\end{array}$ \\
\hline $\begin{array}{l}\text { Internal and external } \\
\text { rotation in the shoulder } \\
\text { joint; transverse plane }\end{array}$ & $\begin{array}{l}\text { Lying on the abdomen, } \\
\text { removal in the shoulder } \\
\text { joint }-90 \text { times, flexion } \\
\text { in the elbow joint }-90 \\
\text { times, pronated forearm }\end{array}$ & $\begin{array}{l}\text { External } \\
\text { rotation - } \\
90 \text { times } \\
\text { Internal } \\
\text { rotation - } \\
90 \text { times } \\
\end{array}$ \\
\hline $\begin{array}{l}\text { Flexion in the elbow } \\
\text { joint; sagittal plane }\end{array}$ & $\begin{array}{l}\text { Sitting or lying down, } \\
\text { forearm is supine }\end{array}$ & $\begin{array}{l}\text { External } \\
\text { rotation - } \\
150 \text { times } \\
\text { Internal } \\
\text { rotation - } \\
150 \text { times }\end{array}$ \\
\hline $\begin{array}{l}\text { Pronation and supina- } \\
\text { tion of the forearm; } \\
\text { transverse plane }\end{array}$ & $\begin{array}{l}\text { Sitting or lying down, } \\
\text { flexion of the elbow joint - } \\
90 \text { times, wrist joint in a } \\
\text { neutral position (interme- } \\
\text { diate between pronation } \\
\text { and supination), fingers } \\
\text { are gripping the pencil }\end{array}$ & $\begin{array}{l}\text { Pronation - } \\
90 \text { times } \\
\text { Supination - } \\
90 \text { times }\end{array}$ \\
\hline $\begin{array}{l}\text { Flexion and extension } \\
\text { in the wrist joint; sagit- } \\
\text { tal plane }\end{array}$ & $\begin{array}{l}\text { Flexion in the elbow } \\
\text { joint }-90 \text { times, forearm } \\
\text { pronated }\end{array}$ & $\begin{array}{l}\text { Bending - } \\
80 \text { times } \\
\text { Extension - } \\
80 \text { times }\end{array}$ \\
\hline $\begin{array}{l}\text { Flexion in the hip joint } \\
\text { during extension in } \\
\text { the knee joint; sagittal } \\
\text { plane }\end{array}$ & $\begin{array}{l}\text { Lying on your back or } \\
\text { side, a leg is stretched at } \\
\text { the knee joint }\end{array}$ & \begin{tabular}{|l|} 
Bending - \\
90 times \\
Extension - \\
90 times \\
\end{tabular} \\
\hline $\begin{array}{l}\text { Withdrawal in the hip } \\
\text { joint; a frontal plane }\end{array}$ & $\begin{array}{l}\text { Lying on your back or } \\
\text { side, a leg is stretched at } \\
\text { the knee joint }\end{array}$ & $\begin{array}{l}\text { Bending - } \\
45 \text { times } \\
\text { Extension - } \\
45 \text { times }\end{array}$ \\
\hline
\end{tabular}

(C) Kharchenko Yevhen, Komarnitska Liudmyla

DOI (article): https://doi.org/10.32626/2227-6246.2021-52.275-298 


\begin{tabular}{|l|l|l|}
\hline $\begin{array}{c}\text { Movement which has } \\
\text { measured and the } \\
\text { plane of motor activity }\end{array}$ & \multicolumn{1}{|c|}{$\begin{array}{c}\text { Starting position } \\
\text { of the patient }\end{array}$} & $\begin{array}{l}\text { Indexes of } \\
\text { the volume } \\
\text { of normal } \\
\text { movements }\end{array}$ \\
\hline $\begin{array}{l}\text { External and internal } \\
\text { rotation in the hip joint; } \\
\text { transverse plane }\end{array}$ & $\begin{array}{l}\text { Lying on your back or sit- } \\
\text { ting, flexion is in the hip } \\
\text { joint and knee joint - 90 } \\
\text { times }\end{array}$ & $\begin{array}{l}\text { External } \\
\text { rotation - } \\
\text { Internal } \\
\text { rotation - } \\
35 \text { times }\end{array}$ \\
\hline $\begin{array}{l}\text { Flexion is in the knee } \\
\text { joint; sagittal plane }\end{array}$ & $\begin{array}{l}\text { Lying on your stomach or } \\
\text { sitting, the hip joint is in } \\
\text { a neutral position }\end{array}$ & $\begin{array}{l}\text { Bending - } \\
135 \text { times } \\
\text { Extension - } \\
135 \text { times }\end{array}$ \\
\hline $\begin{array}{l}\text { Posterior and plantar } \\
\text { flexion in the ankle } \\
\text { joint; sagittal plane }\end{array}$ & $\begin{array}{l}\text { Lying on your back or } \\
\text { sitting, bending at the } \\
\text { knee - 90 times }\end{array}$ & $\begin{array}{l}\text { Rear flexion - } \\
20 \text { times } \\
\text { Plantar } \\
\text { flexion - } \\
50 \text { times }\end{array}$ \\
\hline
\end{tabular}

Also we proposed «Six-point scale for assessing muscle strength» (Table 2).

Six-point scale for assessing muscle strength

\begin{tabular}{|c|c|}
\hline Points & Muscle strength \\
\hline 0 & $\begin{array}{c}\text { There are no signs of stress when the person is trying } \\
\text { to perform arbitrary movement }\end{array}$ \\
\hline 1 & $\begin{array}{l}\text { The feeling of tension when the person is trying } \\
\text { to make an arbitrary movement }\end{array}$ \\
\hline 2 & A movement in full in the conditions of physical unloading \\
\hline 3 & A movement in full under the action of gravity \\
\hline 4 & $\begin{array}{l}\text { A movement in full under the action of gravity } \\
\text { and slight external resistance }\end{array}$ \\
\hline 5 & $\begin{array}{l}\text { A movement in full under the action of force } \\
\text { with maximum external resistance }\end{array}$ \\
\hline
\end{tabular}

(C) Kharchenko Yevhen, Komarnitska Liudmyla DOI (article): https://doi.org/10.32626/2227-6246.2021-52.275-298 
DOI: https://doi.org/10.32626/2227-6246.2021-52

2021. випуск 52

The empirical research was provided at the Department of Human Health and Physical Therapy of the International University of Economics and Humanities named after Academician Stepan Demyanchuk on the basis of Ternopil Regional Municipal Clinical Psychoneurological Hospital, Neurological Department for Patients with Cerebral Circulatory Disorders (Neuroreability Unit).

In accordance with the purpose of the research and in order to solve the tasks, 50 patients with ischemic stroke were participated in our experiment who had disturbances in the area of the internal carotid artery in the acute and residual period, who were treated at the Ternopil Regional Communal Clinical Psycho-neurological Hospital during the period from January to December, 2020.

The diagnosis of ischemic stroke was made in the neurological department for patients with cerebral circulatory disorders on the basis of the characteristic of clinical picture, data of the laboratory and instrumental research methods according to the "International Statistical Classification of Diseases and Related Health Problems».

The criteria for inclusion into the empirical study were: a clear consciousness with sleep disturbance, sufficient to maintain and follow instructions during providing exercises; the absence of severe somatic pathology, acute systemic disease, uncontrolled sinus tachycardia above 120 beats per minute, diabetes mellitus, musculoskeletal defects that in a great degree complicated exercises, a lack of gross sensory aphasia and cognitive disorders patients in the process of providing rehabilitation measures.

The initial examination of patients hospitalized with acute stroke or recurrence of the disease was performed after stabilization of the condition and the main indicators of hemodynamics, general cerebral symptoms (7-14 days), 1.5 hours after meals and medicine in the morning.

(c) Kharchenko Yevhen, Komarnitska Liudmyla

DOI (article): https://doi.org/10.32626/2227-6246.2021-52.275-298 
A very important point of the planned rehabilitation measures is to control the state of the autonomic nervous system and the level of adaptive capacity of the patient in order to eliminate overload and reduce the efficiency of cardiovascular psychomotor support, which can be the result of destabilization of the cardiovascular system.

Functional tests with changes in the parameters of external respiration (test with respiratory arrest on exhalation, hyperventilation test) were performed at rest in the supine position after measuring heart rate and blood pressure. Obtained results when measuring the average data of heart rate and blood pressure at the beginning of the study are shown in Table 3.

Table 3

Heart rate, systolic blood pressure, diastolic blood pressure of patients with ischemic stroke at the beginning of the course of physical rehabilitation $(\mathrm{M} \pm \mathrm{T})$

\begin{tabular}{|l|c|}
\hline \multicolumn{1}{|c|}{ Indicators that are studied } & $\begin{array}{c}\text { The average values of } \\
\text { indicators (in points) }\end{array}$ \\
\hline $\begin{array}{l}\text { Heart rate, beats/min., when it is the } \\
\text { state of rest for the patient }\end{array}$ & $97.9 \pm 3.4$ \\
\hline $\begin{array}{l}\text { Systolic blood pressure, } \mathrm{mm} \mathrm{Hg} \text {, when } \\
\text { it is the state of rest for the patient }\end{array}$ & $173.2 \pm 10.1$ \\
\hline $\begin{array}{l}\text { Diastolic blood pressure, mm Hg, when } \\
\text { it is the state of rest for the patient }\end{array}$ & $93.2 \pm 6.0$ \\
\hline
\end{tabular}

The reaction of patients to the proposed test load at the beginning of the course of physical rehabilitation was characterized in such a way: motor mode 1a was recommended for 50 patients (inadequate response to the test with respiratory arrest was registered). Motor mode $1 \mathrm{~b}$ was recommended for 40 patients (adequate response to the test with respiratory arrest and inadequate response to the hyperventilation test). The adequate response to both breath tests was observed in 10 patients, and such patients were recommended motor mode $2 \mathrm{a}$. There were no patients with an adequate response to the DOI (article): https://doi.org/10.32626/2227-6246.2021-52.275-298 
DOI: https://doi.org/10.32626/2227-6246.2021-52

2021. виПУСК 52

orthostatic test who were identified at the time of the initial examination.

Thus, most patients had a fairly low functional state, which required careful monitoring of the level of physical exercises which were being used. The latter also determined the method of further restoration measures (initial position for classes, duration of classes, the number of exercises performed by the symptom complexes, the frequency of repetition of exercises, the need for more frequent recording of changes in the frequency of heart rate and blood pressure in response to physical activity).

In order to the most adequately study of the conditions and changes in muscle functions of patients with ischemic stroke, we divided patients into clinical subgroups, according to the most common combination of motor deficits of the upper and lower extremities: «hemiplesia» - 12 patients ( $24 \%$ cases), "plesion of the upper limb and paresis of the lower limb» -18 patients ( $36 \%$ of cases), «hemiparesis» -20 patients $(40 \%$ of cases).

The data obtained by us on the state of motor function of patients with ischemic stroke of the subgroup «hemiplegia» are presented in Table 4.

According to the empirical results we have obtained, we have developed a «Functional methodology for the restoration of motor function of patients with ischemic stroke, taking into account their psycho-physiological features», based on the psychological principles of stepwise, sequencing and complexity, as well as on the maximum and adequate psychological impact of the rehabilitation therapist on the patient.

Also we proposed the «Functional methodology of physical rehabilitation in the early period of ischemic stroke». The main provisions of this methodology are:

1. The stabilization of the psycho-emotional state of the patient: reducing the level of anxiety, increasing motivation to exercise in the course of physical rehabilitation.

(c) Kharchenko Yevhen, Komarnitska Liudmyla

DOI (article): https://doi.org/10.32626/2227-6246.2021-52.275-298 
The research data on the volume of active and passive movements, strength and of muscle tone of the affected extremities of patients of the subgroup "hemiplesia» $(\mathrm{n}=12)$ at the beginning of the study $(\mathrm{M} \pm \mathrm{t})$

\begin{tabular}{|c|c|c|c|c|}
\hline $\begin{array}{c}\text { Motor acts being } \\
\text { tested }\end{array}$ & 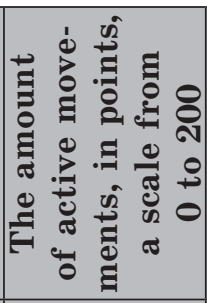 & 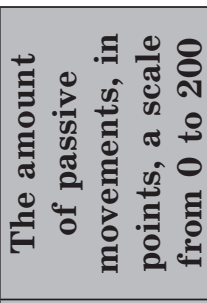 & 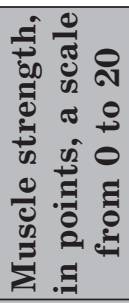 & 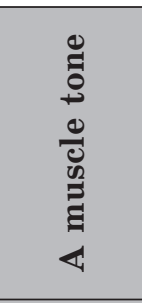 \\
\hline 1 & 2 & 3 & 4 & 5 \\
\hline $\begin{array}{l}\text { Flexion and extension } \\
\text { in the shoulder joint } \\
\text { (the main group) }\end{array}$ & $9.7 \pm 3.5$ & $34.8 \pm 2.5$ & 4 & Reduced \\
\hline $\begin{array}{l}\text { Flexion and extension } \\
\text { in the shoulder joint } \\
\text { (the control group) }\end{array}$ & $10.4 \pm 2.8$ & $33.1 \pm 2.0$ & 3 & Reduced \\
\hline $\begin{array}{l}\text { Withdrawal of the arm } \\
\text { at the shoulder joint } \\
\text { (the main group) }\end{array}$ & $10.3 \pm 2.7$ & $26.8 \pm 1.5$ & 4 & Reduced \\
\hline $\begin{array}{l}\text { Withdrawal of the arm } \\
\text { at the shoulder joint } \\
\text { (the control group) }\end{array}$ & $11.8 \pm 5.2$ & $9.7 \pm 2.6$ & 4 & Reduced \\
\hline $\begin{array}{c}\text { The external and } \\
\text { internal rotation in the } \\
\text { shoulder joint } \\
\text { (the main group) }\end{array}$ & $7.8 \pm 4.1$ & $8.9 \pm 2.4$ & 3 & Reduced \\
\hline $\begin{array}{c}\text { The external and } \\
\text { internal rotation in the } \\
\text { shoulder joint } \\
\text { (the control group) }\end{array}$ & $8.9 \pm 2.5$ & $7.6 \pm 1.2$ & 4 & Reduced \\
\hline $\begin{array}{l}\text { Bending the arm } \\
\text { in elbow joints } \\
\text { (the main group) }\end{array}$ & $15.6 \pm 6.2$ & $14.3 \pm 7.1$ & 5 & Reduced \\
\hline
\end{tabular}

(C) Kharchenko Yevhen, Komarnitska Liudmyla DOI (article): https://doi.org/10.32626/2227-6246.2021-52.275-298 
DOI: https://doi.org/10.32626/2227-6246.2021-52

2021. ВИПУСК 52

\begin{tabular}{|c|c|c|c|c|}
\hline 1 & 2 & 3 & 4 & 5 \\
\hline $\begin{array}{l}\text { Bending the arm } \\
\text { in elbow joints } \\
\text { (the control group) }\end{array}$ & $12.8 \pm 6.7$ & $11.0 \pm 4.2$ & 4 & Reduced \\
\hline $\begin{array}{c}\text { The supination } \\
\text { of forearm } \\
\text { (the main group) }\end{array}$ & $11.8 \pm 1.8$ & $10.3 \pm 4.7$ & 3 & Reduced \\
\hline $\begin{array}{c}\text { The supination } \\
\text { of forearm } \\
\text { (the control group) }\end{array}$ & $10.5 \pm 2.3$ & $11.8 \pm 5.4$ & 4 & Reduced \\
\hline $\begin{array}{c}\text { The pronation } \\
\text { of forearm } \\
\text { (the main group) }\end{array}$ & $12.8 \pm 5.1$ & $14.8 \pm 1.6$ & 4 & Reduced \\
\hline $\begin{array}{c}\text { The pronation } \\
\text { of forearm } \\
\text { (the control group) }\end{array}$ & $10.1 \pm 2.3$ & $16.0 \pm 1.8$ & 4 & Reduced \\
\hline $\begin{array}{c}\text { Flexion and extension } \\
\text { in the wrist } \\
\text { (the main group) }\end{array}$ & $17.3 \pm 2.7$ & $17.1 \pm 4.2$ & 4 & Reduced \\
\hline $\begin{array}{l}\text { Flexion and extension } \\
\text { in the wrist } \\
\text { (the control group) }\end{array}$ & $20.1 \pm 4.3$ & $17.8 \pm 9.5$ & 4 & Reduced \\
\hline $\begin{array}{l}\text { Bending in hip joints } \\
\text { (the main group) }\end{array}$ & $45.6 \pm 7.8$ & $46.9 \pm 2.1$ & 7 & Reduced \\
\hline $\begin{array}{l}\text { Bending in hip joints } \\
\text { (the control group) }\end{array}$ & $49.1 \pm 4.3$ & $44.5 \pm 2.0$ & 6 & Reduced \\
\hline $\begin{array}{l}\text { The extension in hip } \\
\text { joints (the main group) }\end{array}$ & $32.1 \pm 6.4$ & $28.5 \pm 2.0$ & 5 & Reduced \\
\hline $\begin{array}{c}\text { The extension } \\
\text { in hip joints } \\
\text { (the control group) }\end{array}$ & $33.2 \pm 6.7$ & $30.1 \pm 5.4$ & 5 & Reduced \\
\hline $\begin{array}{l}\text { The assignment in hip } \\
\text { joints (the main group) }\end{array}$ & $32.7 \pm 7.1$ & $29.5 \pm 4.1$ & 5 & Reduced \\
\hline $\begin{array}{l}\text { The assignment } \\
\text { in hip joints } \\
\text { (the control group) }\end{array}$ & $34.5 \pm 1.8$ & $30.6 \pm 2.9$ & 5 & Reduced \\
\hline
\end{tabular}

(C) Kharchenko Yevhen, Komarnitska Liudmyla

DOI (article): https://doi.org/10.32626/2227-6246.2021-52.275-298 
DOI: https://doi.org/10.32626/2227-6246.2021-52

2021. випуск 52

\begin{tabular}{|c|c|c|c|c|}
\hline 1 & 2 & 3 & 4 & 5 \\
\hline $\begin{array}{l}\text { Bringing in hip joints } \\
\text { (the main group) }\end{array}$ & $27.6 \pm 6.0$ & $23.4 \pm 7.1$ & 5 & Reduced \\
\hline $\begin{array}{l}\text { Bringing in hip joints } \\
\text { (the control group) }\end{array}$ & $31.8 \pm 2.4$ & $33.0 \pm 5.5$ & 5 & Reduced \\
\hline $\begin{array}{c}\text { The external rotation } \\
\text { in the hip joint } \\
\text { (the main group) }\end{array}$ & $33.9 \pm 5.1$ & $27.0 \pm 1.9$ & 5 & Reduced \\
\hline $\begin{array}{l}\text { The external rotation } \\
\text { in the hip joint } \\
\text { (the control group) }\end{array}$ & $28.1 \pm 7.0$ & $24.5 \pm 6.1$ & 5 & Reduced \\
\hline $\begin{array}{l}\text { The internal rotation } \\
\text { in the hip joint } \\
\text { (the main group) }\end{array}$ & $25.9 \pm 4.7$ & $22.1 \pm 6.1$ & 5 & Reduced \\
\hline $\begin{array}{l}\text { The internal rotation } \\
\text { in the hip joint } \\
\text { (the control group) }\end{array}$ & $23.1 \pm 7.4$ & $24.0 \pm 8.1$ & 5 & Reduced \\
\hline $\begin{array}{l}\text { Bending in knee joints } \\
\text { (the main group) }\end{array}$ & $56.0 \pm 4.8$ & $76.1 \pm 7.6$ & 6 & Reduced \\
\hline $\begin{array}{l}\text { Bending in knee joints } \\
\text { (the control group) }\end{array}$ & $67.1 \pm 7.2$ & $79.4 \pm 6.5$ & 6 & Reduced \\
\hline $\begin{array}{l}\text { Bending in ankle joints } \\
\text { (the main group) }\end{array}$ & $34.9 \pm 1.2$ & $38.7 \pm 5.2$ & 5 & Reduced \\
\hline $\begin{array}{l}\text { Bending in ankle joints } \\
\text { (the control group) }\end{array}$ & $30.0 \pm 4.1$ & $33.2 \pm 7.1$ & 5 & Reduced \\
\hline $\begin{array}{l}\text { The extension in ankle } \\
\text { joints (the main group) }\end{array}$ & $43.1 \pm 6.1$ & $40.0 \pm 6.3$ & 5 & Reduced \\
\hline $\begin{array}{c}\text { The extension } \\
\text { in ankle joints } \\
\text { (the control group) }\end{array}$ & $44.9 \pm 2.3$ & $41.9 \pm 6.4$ & 5 & Reduced \\
\hline
\end{tabular}

2. The actualization of stable static and dynamic stereotypes of the patient in all initial positions - from horizontal to vertical ones, using the influence of simple, eye-motor, tonic (labyrinthine tonic reflexes, symmetrical cervical tonic reflex, cervical asymmetric tonic reflex, etc.). Restoration and main-

(C) Kharchenko Yevhen, Komarnitska Liudmyla DOI (article): https://doi.org/10.32626/2227-6246.2021-52.275-298 
DOI: https://doi.org/10.32626/2227-6246.2021-52

2021. випуск 52

tenance of stress resistance of patients is provided by symmetrical maintenance of a projection of the general center of gravity on a basic surface in such initial positions in which normal proper afferentation of joints and muscles will be stimulated. These are the positions that the human body consistently takes in the process of verticalization: a supine position on the back; a lying position on the side (right and left); a supine position; a standing position on the knees; a standing position on the knees (with additional vertical support and without such a support); a standing position (with additional vertical support and without such a support).

It was proved that the starting position became a directly activated position with a torso extension, which had the aim to support all muscle groups of the patient, provided by the stimulation of a successive chain of muscle contractions directed from the center to the periphery of the body. The symmetry of maintaining the initial position of the patient during the lesson is constantly adjusted (passively or actively) in order to stimulate proper afferentation.

\section{Conclusions}

The main directions of psychotherapy and psycho-correction of patients who suffered from ischemic stroke are:

- the assistance in the process of understanding the patients, his / her basic needs, motives, instructions, relationships; his / her internal conflicts and mechanisms of psychological protection; features of his / her behavior and emotional response, their adequacy and realism;

- the correction of patients' instructions;

- the assistance in formulating and securing adequate forms of patients' behavior based on personal achievements in the cognitive, motivational, and emotional spheres;

- the promotion of positive motivation for recovery and increased activity in treatment at the behavioral level.

(C) Kharchenko Yevhen, Komarnitska Liudmyla

DOI (article): https://doi.org/10.32626/2227-6246.2021-52.275-298 
DOI: https://doi.org/10.32626/2227-6246.2021-52

2021. випУСК 52

During the classes according to the proposed methodology, we have the aim to achieve the stabilization of a psycho-emotional state of the patient through the correction of his / her cognitive processes that motivate the patient to actions which generally affect the effectiveness of all rehabilitation measures.

\section{Literature}

Epstein, R., Blake, J. J., \& González, T. (2017). Girlhood interrupted: the erasure of black girls' childhood. Washington, DC : Georgetown Law Center on Poverty and Inequality. URL: https://www.law.georgetown. edu/poverty-inequality-center/wp-content/uploads/sites/14/2017/ 08/girlhood-interrupted.pdf.tab.

Hardeman, Rachel R., Medina, Eduardo M., \& Kozhimannil, Katy B. (2016). Structural Racism and Supporting Black Lives - The Role of Health Professionals. New England Journal of Medicine, 375 (22), 21132115. DOI 10.1056/NEJMp1609535.

Hayden, F. G., Farrar, J., \& Peiris, J. S. (2014). Towards improving clinical management of Middle East respiratory syndrome coronavirus infection. Lancet Infect Dis., 14 (7), 544-546. DOI 10.1016/S14733099(14)70793-5.

Khwaja, A. (2012). KDIGO clinical practice guidelines for acute kidney injury. Nephron Clin Pract, 120, 179-84.

Mykhalchuk, Nataliia, Pelekh, Yurii, Kharchenko, Yevhen, Ivashkevych, Eduard, Ivashkevych, Ernest, Prymachok, Lyudmyla, Hupavtseva, Nataliia, \& Zukow, Walery (2020). The empirical research of the professional reliability of 550 doctors during the COVID-19 pandemic in Ukraine (March-June 2020). Balneo Research Journal. Vol. 11. No. 3, September 2020. P. 393-404. DOI http://dx.doi.org/ $10.12680 /$ balne.

Onufriieva, L., Chaikovska, O., Kobets, O., Pavelkiv, R., \& Melnychuk, T. (2020). Social Intelligence as a Factor of Volunteer Activities by Future Medical Workers. Journal of History Culture and Art Research. Vol. 9. № 1. P. 84-95. DOI http://dx.doi.org/10.7596/taksad.v9i1. 2536.

Villar, J., Blanco, J., \& del Campo, R. (2015). Spanish Initiative for Epidemiology, Stratification \& Therapies for ARDS (SIESTA) Network. Assessment of $\mathrm{PaO} / \mathrm{FiO}$ for stratification of patients with moderate and severe acute respiratory distress syndrome. BMJ Open, 5 (3). DOI 10.1136/bmjopen-2014-006812.

(C) Kharchenko Yevhen, Komarnitska Liudmyla DOI (article): https://doi.org/10.32626/2227-6246.2021-52.275-298 


\section{References}

Epstein, R., Blake, J. J., \& González, T. (2017). Girlhood interrupted: the erasure of black girls' childhood. Washington, DC : Georgetown Law Center on Poverty and Inequality. Retrieved from https://www. law.georgetown.edu/poverty-inequality-center/wp-content/uploads/ sites/14/2017/08/girlhood-interrupted.pdf.tab.

Hardeman, Rachel R., Medina, Eduardo M., \& Kozhimannil, Katy B. (2016). Structural Racism and Supporting Black Lives - The Role of Health Professionals. New England Journal of Medicine, 375 (22), 21132115. DOI 10.1056/NEJMp1609535.

Hayden, F. G., Farrar, J., \& Peiris, J. S. (2014). Towards improving clinical management of Middle East respiratory syndrome coronavirus infection. Lancet Infect Dis., 14 (7), 544-546. DOI 10.1016/S14733099(14)70793-5.

Khwaja, A. (2012). KDIGO clinical practice guidelines for acute kidney injury. Nephron Clin Pract, 120, 179-84.

Mykhalchuk, Nataliia, Pelekh, Yurii, Kharchenko, Yevhen, Ivashkevych, Eduard, Ivashkevych, Ernest, Prymachok, Lyudmyla, Hupavtseva, Nataliia, \& Zukow, Walery (2020). The empirical research of the professional reliability of 550 doctors during the COVID-19 pandemic in Ukraine (March-June 2020). Balneo Research Journal, 11 (3), 393-404. DOI http://dx.doi.org/10.12680/balne.

Onufriieva, L., Chaikovska, O., Kobets, O., Pavelkiv, R., \& Melnychuk, T. (2020). Social Intelligence as a Factor of Volunteer Activities by Future Medical Workers. Journal of History Culture and Art Research, 9 (1), 84-95. DOI http://dx.doi.org/10.7596/taksad.v9i1.2536.

Villar, J., Blanco, J., \& del Campo, R. (2015). Spanish Initiative for Epidemiology, Stratification \& Therapies for ARDS (SIESTA) Network. Assessment of $\mathrm{PaO} / \mathrm{FiO}$ for stratification of patients with moderate and severe acute respiratory distress syndrome. BMJ Open, 5 (3). DOI 10.1136/bmjopen-2014-006812.

\section{Харченко Євген, Комарніцька Людмила. Теоретичні основи психологічної та фізичної реабілітації хворих ішемічним інсультом}

\section{АНОТАЦІЯ}

Завдання статmi - вивчити особливості розладів психомоторної функції та психоемоційного стану хворих на ішемічний інсульт за даними первинного обстеження; розробити методику фізичної та психологічної реабілітації хворих на ішемічний інсульт на стаціонарному етапі реабі-

(C) Kharchenko Yevhen, Komarnitska Liudmyla

DOI (article): https://doi.org/10.32626/2227-6246.2021-52.275-298 http://journals.uran.ua/index.php/2227-6246 
літації залежно від тяжкості ураження психомоторних функцій і особливостей психоемоційного стану; у психолого-педагогічному експерименті оцінити ефективність запропонованої методики фрізичної та психологічної реабілітації хворих на ішемічний інсульт на стаціонарному етапі реабілітації.

Для розв'язання сформульованих у роботі завдань було використано такі теоретичні методи дослідження: категоріальний метод, структурно-функціональний метод, методи аналізу, систематизації, моделювання, узагальнення. Також у своєму дослідженні нами використано емпіричні методи, такі як спостереження, інтерв'ю, анкетування, метод психомедичного експерименту, тестування (тест М. Люшера).

Результати дослідження. Розроблено "Функціональну методику відновлення рухової функції хворих ішемічним інсультом з урахуванням їх психофрізіологічних особливостей», засновану на психологічних принципах поетапності, послідовності та комплексності, а також на максимальному й адекватному психологічному впливові реабілітолога на пачієнта.

Запропоновано "Функціональну методику фрізичної реабілітації в ранньому періоді ішемічного інсульту». Основними положеннями цієї методики є: 1. Стабілізація психоемоційного стану пацієнта: зниження рівня тривожності, підвищення мотивації до занять фрізичними вправами з курсу фізичної реабілітації.

2. Актуалізація стабільного статичного і динамічного стереотипів пацієнта в усіх вихідних положеннях - від горизонтального до вертикального, з використанням впливу простих, окорухових, тонічних (лабіринтові тонічні рефлекси, симетричний шийний тонічний рефрлекс, шийний асиметричний тонічний рефлекс тощо) рефлексів. Відновлення та збереження стресостійкості хворих забезпечується симетричним утриманням проекції загального центру ваги на опорну поверхню в таких вихідних положеннях, у яких стимулюватиметься нормальна належна афрерентація суглобів і м'язів. Ідеться про позиції, які послідовно приймає людський організм у прочесі вертикалізації: позиція лежачи на спині; позиція лежачи на боці (правому і лівому); позиція лежачи на живоmi; позиція стоячи навкарачки; позиція стоячи на колінах (із додатковою вертикальною опорою і без опори); позиція стоячи (з додатковою вертикальною опорою і без опори).

Доведено, що вихідна позиція стає безпосередньо активованою позицією з витягуванням тулуба. Вона спрямована на підтримку всіх груп

(C) Kharchenko Yevhen, Komarnitska Liudmyla DOI (article): https://doi.org/10.32626/2227-6246.2021-52.275-298 
DOI: https://doi.org/10.32626/2227-6246.2021-52

2021. випуск 52

м'язів пацієнта, що забезпечується стимулячією послідовного ланцюжка м'язових скорочень, спрямованих від чентру до периферії тіла. Симетричність підтримки вихідного положення пацієнта у процесі заняття постійно коригується (пасивно або активно) з метою стимуляції належної арерентації.

Висновки. Основними напрямками психотерапії та психокорекції у хворих, які перенесли ішемічний інсульт, є: допомога в усвідомленні пацієнтом його основних потреб, мотивів, настановлень, взаємовідносин; його внутрішніх конфліктів і механізмів психологічного захисту; особливостей його поведінки й емоційного реагування, їх адекватності та реалістичності; корекція настановлень пацієнта; допомога у формулюванні та закріпленні адекватних форм поведінки на підставі особистісних досягнень у пізнавальній, мотиваційній, емочійній срерах; сприяння підвищенню позитивної мотивації на одужання і збільшення активності в боротьбі з хворобою на поведінковому рівні.

У ході проведення занять за запропонованою методикою ми досягли стабілізації психоемоційного стану хворого шляхом корекції пізнавальних процесів, які спонукали хворого до дій, що загалом впливали на ефективність усіх реабілітаційних заходів.

Ключові слова: ішемічний інсульт, психоемочійний стан пацієнтів, фізична реабілітація, психологічна реабілітація, особисті досягнення, когнітивна срера, мотивачійна сфрера, емочійна срера.

Харченко Евгений, Комарницкая Людмила. Теоретические основы психологической и физической реабилитации больных ишемическим инсультом

\section{АННОТАЦИЯ}

Задачи статьи - изучить особенности расстройств психомоторной функции и психоэмоционального состояния больных ишемическим инсультом на основе данных первичного обследования; разработать методику физической и психологической реабилитации больных ишемическим инсультом на стационарном этапе реабилитации в зависимости от тяжести поражения психомоторных функций и особенностей психоэмоционального состояния больных; в психолого-педагогическом эксперименте оценить эффективность предложенной методики физической (c) Kharchenko Yevhen, Komarnitska Liudmyla

DOI (article): https://doi.org/10.32626/2227-6246.2021-52.275-298 http://journals.uran.ua/index.php/2227-6246 
DOI: https://doi.org/10.32626/2227-6246.2021-52

2021. вИПУСК 52

и психологической реабилитации больных ишемическим инсультом на стационарном этапе реабилитации.

Для нахождения путей решения сформулированных в работе задач были использованы следующие теоретические методы исследования: категориальный метод, структурно-функциональный метод, методы анализа, систематизации, моделирования, обобщения. Также в своем исследовании мы использовали эмпирические методы, такие как наблюдение, интервью, анкетирование, метод психомедицинского исследования, тестирование (тест М. Люшера).

Результаты исследования. Разработана «Функциональная методика восстановления двигательной функции больных ишемическим инсультом с учетом их психофизиологических особенностей», основанная на психологических принципах поэтапности, последовательности и комплексности, а также на максимальном и адекватном психологическом воздействии педагога на пациента.

Предложена «Функциональная методика физической реабилитации в раннем периоде ишемического инсульта». Основными положениями этой методики являются:

1. Стабилизация психоэмоционального состояния пациента: снижение уровня тревожности, повышение мотивации к занятиям фризическими упражнениями по курсу физической реабилитации.

2. Актуализация стабильного статического и динамического стереотипов пациента во всех исходных положениях - от горизонтального до вертикального, с использованием влияния простых, глазодвигательных, тонических (лабиринтные тонические рефлексы, симметричный шейный тонический рефлекс, шейный асимметричный тонический рефлекс и др.) рефлексов. Восстановление и сохранение стрессоустойчивости больных обеспечивается симметричным удержанием проекции общего центра тяжести на опорную поверхность в таких исходных положениях, в которых будет стимулироваться нормальная надлежащая афферентация суставов и мыши. Речь идет о позициях, которые последовательно принимает человеческий организм в процессе вертикализации: позиция лежа на спине; позиция лежа на боку (правом и левом); позиция лежа на животе; позиция стоя на четвереньках; позиция стоя на коленях (с дополнительной вертикальной опорой и без опоры); позиция стоя (с дополнительной вертикальной опорой и без опоры).

(C) Kharchenko Yevhen, Komarnitska Liudmyla DOI (article): https://doi.org/10.32626/2227-6246.2021-52.275-298 
DOI: https://doi.org/10.32626/2227-6246.2021-52

2021. випуск 52

Доказано, что исходная позиция становится непосредственно активированной позицией с вытяжкой туловища. Данная позиция направлена на поддержку всех групп мыши пациента; она обеспечивается стимулячией последовательной чепочки мышечных сокращений, направленных от центра к периферии тела. Симметричность поддержки исходного положения пациента в процессе занятия постоянно корректируется (пассивно или активно) с целью стимуляции надлежащей афррерентации.

Выводы. Основными направлениями психотерапии и психокоррекции у больных, перенесших ишемический инсульт, являются: помощь в осознании пациентом его основных потребностей, мотивов, установок, отношений; его внутренних конфлликтов и механизмов психологической защиты; особенностей его поведения и эмоционального реагирования, их адекватности и реалистичности; коррекция установок пациента; помощь в формулировании и закреплении адекватных форм поведения на основании личностных достижений в познавательной, мотивационной, эмоциональной срерах; содействие повышению положительной мотивации на выздоровление и увеличение активности в борьбе с болезнью на поведенческом уровне.

В ходе проведения занятий с использованием предложенной методики мы достигли стабилизации психоэмоционального состояния больного путем коррекции познавательных процессов, которые фасилитировали больного к действиям и в целом влияли на эффрективность всех реабилитационных мероприятий.

Ключевые слова: ишемический инсульт, психоэмочиональное состояние пациентов, физическая реабилитация, психологическая реабилитация, личностные достижения, когнитивная срера, мотивационная сфрера, эмоциональная сфера.

Original manuscript received February 23, 2021 Revised manuscript accepted April 18, 2021

(C) Kharchenko Yevhen, Komarnitska Liudmyla

DOI (article): https://doi.org/10.32626/2227-6246.2021-52.275-298 